Zabytkoznawstwo i Konserwatorstwo XXXIX, Toruń 2010

Mirosław Wachowiak, Mirosław Sawczak

Uniwersytet Mikołaja Kopernika w Toruniu

\title{
Nieinwazyjna metoda identyfikacji pigmentów in situ - badania przenośnym spektroskopem XRF obrazów olejnych Józefa Pankiewicza*
}

\section{Wprowadzenie}

Winiejszy tekst jest poświęcony nieinwazyjnej metodzie identyfikacji pigskładu pierwiastkowego warstwy malarskiej obrazów, za pomocą przenośnego spektrometru XRF, skonstruowanego w Instytucie Maszyn Przepływowych PAN w Gdańsku.

Badania składu pierwiastkowego pigmentów warstwy malarskiej obrazów olejnych Józefa Pankiewicza, pochodzących z lat 1888-1938, przeprowadzono na 39 obiektach z Muzeum Narodowego w Krakowie, Poznaniu oraz z Muzeum Śląskiego w Katowicach ${ }^{1}$. Poprzedzono je badaniami na wzorcach - próbkach farb współczesnych o składzie porównywalnym z farbami używanymi historycznie w okresie reprezentowanym przez dzieła

* Badania sfinansowano ze środków Komitetu Badań Naukowych w ramach grantu promotorskiego przyznanego w roku 2006.

1 Badania stanowią cześć pracy doktorskiej Malarstwo olejne Józefa Pankiewicza - materiat i technika, pisanej przez M. Wachowiaka pod kierunkiem prof. dr. hab. D. Markowskiego na Wydziale Sztuk Pięknych UMK w Toruniu. Tekst jest rozszerzoną wersją prezentacji w formie posteru: M. Wachowiak, M. Sawczak, K. Komar, D. Markowski, G. Śliwiński, Pigment identification in Pankiewicz's works by means of XRF and LIBS, [w:] Lacona VII Conference, 17-21 September 2007, Madrid, oraz tekstu Investigation of paint layers in the collection of Pankiewicz's works (1888-1938) by means of the portable XRF, LIBS and fluorescence imaging techniques, [w:] Lacona VII. Book of abstracts, Madrid 2007, s. 119. 
Pankiewicza ${ }^{2}$. Badano czyste próbki farb, ich mieszaniny oraz warstwy pokrywających się kolorów. W celu porównania z wynikami uzyskanymi dla warstwy malarskiej obrazów przebadano ponadto próbki czystych kolorów historycznych: niezmieszanych farb z palety Jana Matejki z 1888 roku oraz farby z tubek z kasety malarskiej anonimowego malarza, datowanej na czas po $1900 \mathrm{roku}^{3}$.

\section{Procedura pomiarowa}

Badania prowadzono z użyciem przenośnego spektrometru XRF, skonstruowanego w IMP PAN w Gdańsku. Szczególny obszar wykorzystania tego przyrządu to pomiary in situ składu pierwiastkowego dzieł sztuki, których nie można przebadać w warunkach laboratoryjnych ${ }^{4}$.

$\mathrm{Z}$ uwagi na przeprowadzanie pomiaru $\mathrm{w}$ atmosferze powietrza, zakres detekcji spektrometru jest ograniczony do pierwiastków o liczbie atomowej Z > 18. Zastosowanie wysokoenergetycznego generacyjnego źródła wzbudzenia (IS601.5, Italstructures), produkującego skolimowaną wiązkę

2 Za wyjatkiem bieli ołowiowej firmy Daler Rowney (Flake white PW 1/PW 4), wszystkie badane wspólczesne farby olejne to produkty firmy Talens (seria Rembrandt lub van Gogh): biel cynkowa (PW 4), biel tytanowa (PW 6/PW 4), żółcień kadmowa cytrynowa (PY 35), oranż kadmowy (PO 20), ugier (żółta ochra PY 42), cynober, alizaryna (alizarin crimson PR 83), kadmowa jasna (PR 108), róż angielski (PR 101), umbra palona (PBr 7), ceruleum (PB 35), błękit kobaltowy jasny (PB 28), błękit pruski (PB 27), ultramaryna sztuczna (PB 29), fiolet kobaltowy (PV 14), fiolet manganowy (permanentny PV 16), zieleń szmaragdowa (PG 18), ziemia zielona (PG 17), zieleń kobaltowa (PG 26), czerń kostna (z kości słoniowej PBk 9).

3 Własność Muzeum Narodowego w Poznaniu, większość tubek z kasety malarskiej to produkty firmy Sennelier, część firmy Lefranc, pojedyncze pochodzą z innych firm (Artés, Schönfeld), nie wszystkie farby udało się zidentyfikować z nazwy i przypisać producentowi, ze względu na nieczytelność zabrudzonych farbą etykiet.

4 Pomiary w muzeach wykonali dr M. Sawczak, dr R. Jędrzejewski, Zakład Fotofizyki IMP PAN, Gdańsk, wyniki zanalizował i zinterpretował M. Wachowiak. Jednym z pierwszych w Polsce opisów możliwości ogólnego zastosowania instrumentu do badań konserwatorskich jest artykuł: M. Sawczak, A. Kamińska, M. Poksińska, A. Cupa, G. Śliwiński, Przenośny spektrometr XRF do badań obiektów zabytkowych, [w:] Techniki analityczne w konserwacji zabytków. Seminarium i warsztaty, Gdańsk, 8-9 czerwca 2006, s. 73-78. 
o średnicy $4 \mathrm{~mm}$, oraz detektora (AXAS, Ketek) o dużej rozdzielczości energetycznej (FWHM < = $155 \mathrm{eV}$ dla linii $\mathrm{Mn}_{\mathrm{K \alpha}}$ ) umożliwia rejestrację linii spektralnych $\mathrm{K}$ pierwiastków, aż do liczby atomowej $\mathrm{Z} \approx 50$. Wysoka czułość i rozdzielczość przyrządu pozwoliła na detekcję nawet śladowych ilości pierwiastków w warstwie malarskiej.

Głębokość penetracji podczas pomiaru jest zależna od analizowanego materiału. W przypadku metali, w zależności od masy atomowej, głębokość ta może się zmieniać w zakresie od kilkunastu do kilkudziesięciu mikrometrów, natomiast w przypadku materiałów słabo absorbujących promieniowanie rentgenowskie, np. warstw malarskich zawierających lekkie pierwiastki, może ona dochodzić do kilkuset mikrometrów.

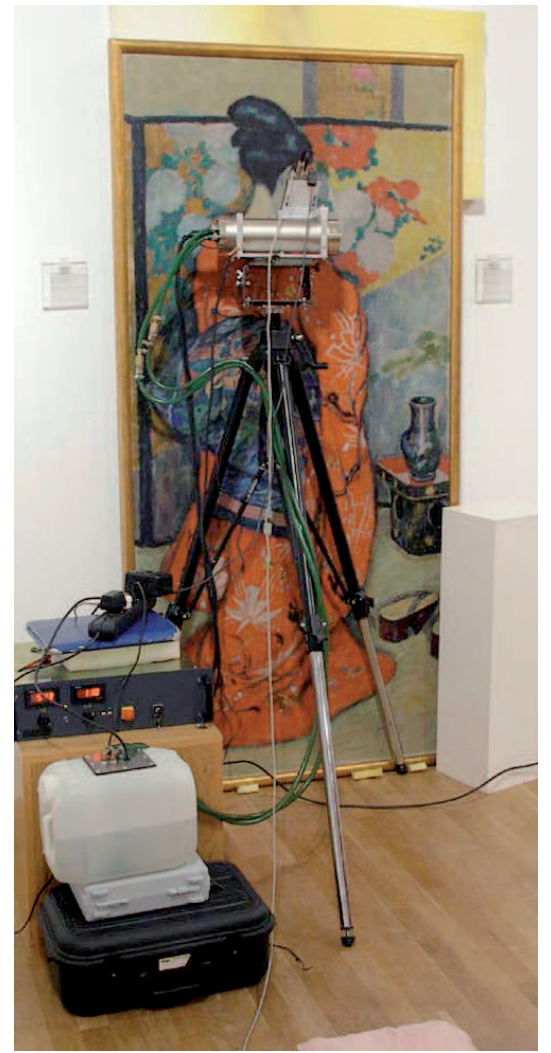

Il. 1. SpektrometrXRF (skonstruowany w IMP Gdańsk) w trakcie pomiarów na obrazie Japonka (1908) w Muzeum Narodowym w Krakowie (fot. P. Frączek)

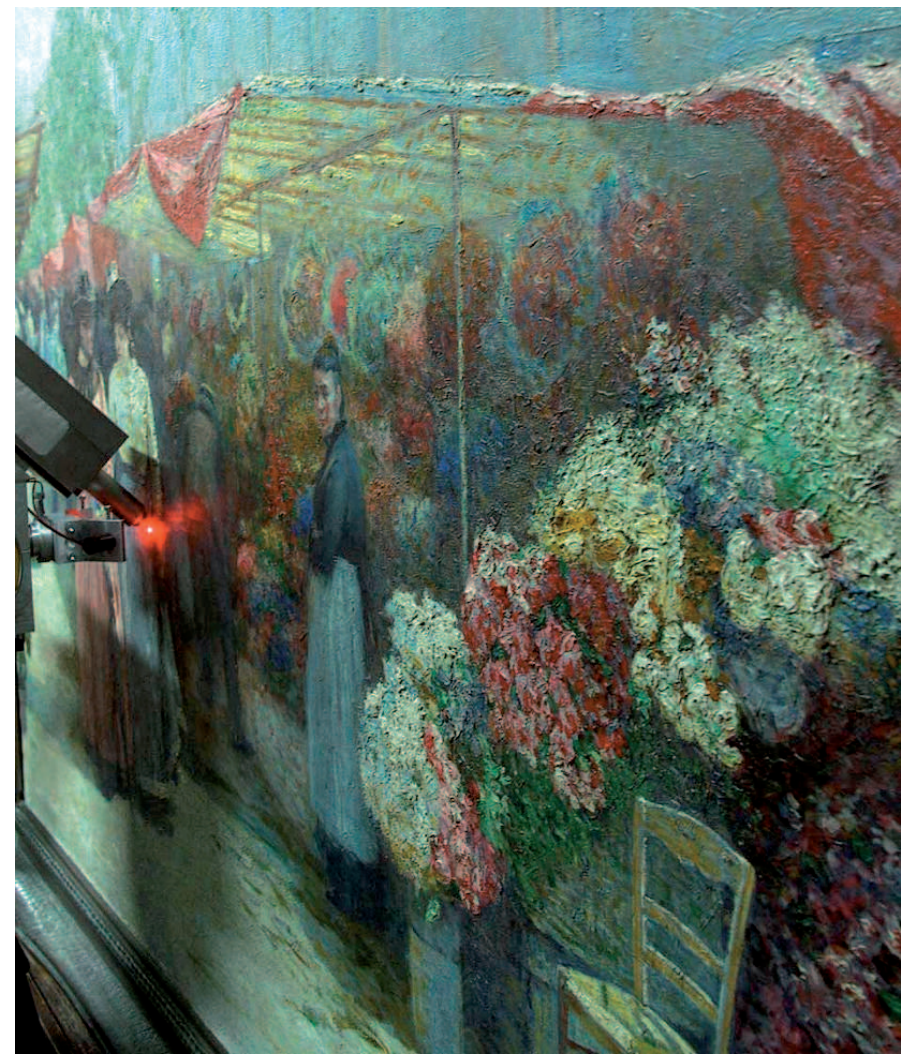

Il. 2. Spektrometr XRF (skonstruowany w IMP Gdańsk) w trakcie pomiarów na obrazie Targ na kwiaty (1890) w Muzeum Narodowym w Poznaniu (fot. M. Wachowiak) 
W omawianych w niniejszym opracowaniu badaniach na obiektach analize spektroskopową XRF prowadzono punktowo w wybranych fragmentach obrazów, selekcjonowanych na podstawie wstępnych badań. Źródło wzbudzenia spektrometru XRF pracowało przy napięciu $55 \mathrm{kV}$ i prądzie $1 \mathrm{~mA}$. Czas zliczania pojedynczego widma wynosił $120 \mathrm{~s}$.

Pomiary poprzedzano obserwacją lica obrazów w promieniowaniu UV i IR w celu wykluczenia wykonywania pomiaru dla fragmentów o nieoryginalnej warstwie malarskiej.

\section{Interpretacja wyników}

Średnie natężenie linii charakterystycznych pierwiastków w widmie XRF zależy głównie od masy atomowej pierwiastka i dla pigmentów warstwy malarskiej badanych na obrazach waha się w szerokim przedziale od około 25000 zliczeń dla ołowiu w bieli ołowianej do około 120 dla manganu w umbrze (tab. 1).

Wartość zliczeń dla danego pierwiastka zasadniczo jest proporcjonalna do jego ilości w badanej próbce, jednak zależność ta nie jest liniowa. $\mathrm{Na}$ intensywność rejestrowanego sygnału wpływa również: reabsorpcja - absorpcja promieniowania charakterystycznego pierwiastków przez atomy matrycy; ekranowanie - zasłanianie warstw spodnich przez wierzchnie; stan powierzchni próbki i jej kształt (w przypadku badań na obrazie np. jego faktura, warstwy powierzchniowe brudu i werniksu); geometria pomiaru - wzajemne położenie względem siebie źródła promieniowania, detektora oraz badanego obiektu/próbki.

W przypadku badań prowadzonych na próbkach przygotowanych laboratoryjnie parametry te można kontrolować, dzięki czemu możliwe są przybliżone pomiary ilościowe oraz - po przeprowadzeniu skalowania - precyzyjne oznaczenie stosunku zliczeń poszczególnych pierwiastków zawartych w danym pigmencie. W przypadku badań na obiektach rzeczywistych, a w szczególności omawianych tu badań warstw malarskich, interpretacja wyników jest utrudniona i należy je traktować głównie jako jakościowe, rozszerzane, gdy to jest możliwe, o przybliżoną ocenę quasi-ilościową. 
Tab. 1. Średnia i najwyższa (próbki czystego koloru często kładzionego w impaście) wartość zliczeń „wiodącego” w pigmencie pierwiastka, zmierzona na olejnych obrazach Pankiewicza z lat 1888-1938 (wartości oznaczone dla parametrów pomiaru podanych w podrozdziale Procedura pomiarowa)

\begin{tabular}{|c|c|c|c|}
\hline Pigment & $\begin{array}{c}\text { Pierwiastek } \\
\text { charakterystyczny }\end{array}$ & $\begin{array}{c}\text { Średnia wartość } \\
\text { zliczeń pierwiastka } \\
\text { na obrazach }\end{array}$ & $\begin{array}{l}\text { Najwyższa wartość } \\
\text { zliczeń w obrazach }\end{array}$ \\
\hline Biel ołowiana & $\mathrm{Pb}$ & 25000 & 39749 \\
\hline Biel cynkowa & $\mathrm{Zn}$ & 18000 & 89010 \\
\hline Cynober & $\mathrm{Hg}$ & 2850 & 24804 \\
\hline Czerwień kadmowa & $\mathrm{Cd},(\mathrm{Se})$ & 2700 & 22754 (Se 7764$)$ \\
\hline Żółcień kadmowa & $\mathrm{Cd}$ & 1200 & 24838 \\
\hline Ceruleum & Sn & 1000 & 2605 \\
\hline Fiolet kobaltowy & Co & 900 & 10409 \\
\hline Żółcień neapolitańska & $\mathrm{Sb}$ & 850 & 5049 \\
\hline Siena & $\mathrm{Fe}$ & 800 & 8395 \\
\hline Umbra & $\mathrm{Fe}$ & 800 & 8420 \\
\hline Zieleń szmaragdowa & $\mathrm{Cr}$ & 450 & 4082 \\
\hline Zieleń szwajnfurcka & $\mathrm{Cu}$ & 420 & 17721 \\
\hline Żółcień strontowa & $\mathrm{Sr}$ & 380 & 42729 \\
\hline Czerwień organiczna & $\mathrm{Sn}$ & 370 & 6571 \\
\hline Żólcienie chromowe & $\mathrm{Cr}$ & 350 & 3295 \\
\hline Błękit kobaltowy & $\mathrm{Co}$ & 320 & 1255 \\
\hline Ugier & $\mathrm{Fe}$ & 300 & 1353 \\
\hline Błękit pruski & $\mathrm{Fe}$ & 240 & 473 \\
\hline Umbra & $\mathrm{Mn}$ & 120 & 382 \\
\hline
\end{tabular}

Źródłami błędu przy ocenie ilościowej pigmentu w warstwie malarskiej są przede wszystkim: nieznajomość grubości warstwy pigmentu oraz struktury powłoki malarskiej, nieznana koncentracja pigmentu w spoiwie, obecność silnie absorbujących promieniowanie domieszek pigmentów zawierających np. ołów (tab. 2), nierówna powierzchnia powłoki malarskiej, pokryta niejednokrotnie warstwą werniksu i zabrudzeń o zmiennej grubości. Podstawowym problemem przy interpretacji wielowarstwowych struktur powłok malarskich techniką XRF jest niemożliwość rozróżnienia, na jakiej 
głębokości znajduje się pierwiastek/pigment widoczny w widmie fluorescencyjnym. Proporcje wartości zliczeń pierwiastków względem siebie zakłóca ekranowanie warstw spodnich (im są liczniejsze, tym trudniejsza jest interpretacja) przez wierzchnie oraz reabsorpcja pierwiastków w mieszaninie kilku pigmentów w obrębie jednej warstwy. Ograniczeniem analizy ilościowej pierwiastków obok ekranowania jest również fakt, że pewna cześć piku przy podstawie nie zawsze pochodzi tylko z danego pierwiastka i może nieco zawyżać wartość zliczenia. Wartość ta rośnie także wtedy, gdy piki dwóch pierwiastków nachodzą na siebie lub wprost się pokrywają, jak np. w przypadku linii L $\alpha$ ołowiu i arsenu, gdy wystęują w próbce równocześnie. Istotne jest również wzięcie pod uwagę fluorescencji własnej spektrometru występującej dla takich pierwiastków, jak: $\mathrm{Fe}, \mathrm{Zr}, \mathrm{Pb}, \mathrm{Ag}$, Sn, zwłaszcza przy analizie niewielkich ilości tych pierwiastków.

Pomimo wymienionych czynników utrudniających analize ilościową składu pigmentów w warstwach malarskich, przeprowadzone w ramach niniejszej pracy badania wykazały, że możliwa jest skuteczna identyfikacja pigmentów, a w wielu przypadkach analiza quasi-ilościowa, sugerująca ich udział w mieszaninie, na podstawie analizy stosunków natężeń linii charakterystycznych pierwiastków wchodzących w ich skład. Istotna jest duża liczba punktów pomiarowych, umożliwiająca porównanie intensywności sygnału pierwiastka obecnego w czystym (prawie czystym) pigmencie, w mieszaninach „pośrednich” (ok. 1:1) oraz jako niewielka domieszka do innych kolorów. Pomocne jest również uwzględnienie więcej niż jednego obrazu artysty z badanego okresu.

Dla wybranej grupy pigmentów otrzymano stałe proporcje zliczeń danych pierwiastków składowych zestawianych ze sobą, o różnicy maksymalnie 4\% (średnio różnica ta wynosiła około 1,5\%, tab. 2a). Szacunki ilościowe i ustalanie proporcji pierwiastków wiodących w danym kolorze pozwalają do pewnego stopnia na orzekanie, z którym z pokrewnych pigmentów o podobnym składzie mamy do czynienia. Na przykład oranż kadmowy od czerwieni kadmowej (w próbkach wzorcowych farb współczesnych) rozróżniono ze względu na stosunek liczby zliczeń kadmu do selenu. Wartość zliczeń selenu w kolejnych pomiarach wynosiła około 76\% dla czerwieni i około 96\% dla oranżu - stąd nawet w mieszaninie z innym pigmentem właściwa identyfi- 
kacja jest prawdopodobna (tab. 2b). Również dla innych kolorów (tab. 2a) otrzymywano stałe proporcje pierwiastków charakterystycznych.

Tab. 2a, b. Stałe proporcje zliczeń dla charakterystycznych pierwiastków w pigmentach: a) Fe/Mn w umbrze; b) Cd/Se w oranżu kadmowym

a)

\begin{tabular}{|c|c|c|}
\hline \multicolumn{3}{|c|}{ Umbra } \\
\hline \multicolumn{2}{|c|}{ wartość zliczeń } & \multirow{2}{*}{$\begin{array}{c}\text { wartość zliczeń } \\
\text { Fe [\%] }\end{array}$} \\
\hline $\mathrm{Fe}$ & $\mathrm{Mn}$ & \\
\hline 8017 & 1112 & 87,8 \\
\hline 7308 & 1068 & 87,2 \\
\hline 5708 & 826 & 87,3 \\
\hline 5118 & 766 & 86,9 \\
\hline 3203 & 534 & 85,7 \\
\hline
\end{tabular}

b)

\begin{tabular}{|c|c|c|}
\hline \multicolumn{3}{|c|}{ Oranż kadmowy } \\
\cline { 1 - 2 } wartość zliczeń & \multirow{2}{*}{$\begin{array}{c}\text { wartość zliczeń } \\
\text { Cd [\%] }\end{array}$} \\
\hline Cd & Se & 96,0 \\
\hline 78819 & 3248 & 94,5 \\
\hline 46625 & 2703 & 92,9 \\
\hline 19092 & 1453 & 92,3 \\
\hline 10848 & 910 & 92,3 \\
\hline 9496 & 406 & 95,9 \\
\hline
\end{tabular}

W przypadku analizy czerwieni kadmowej na obiektach w trakcie pomiarów dwóch różnych obrazów (Róże, MNK, 1917-1918, oraz Anemony, MNP, 1924) otrzymano proporcje zliczeń kadmu do selenu odpowiednio: $74,4: 25,6$ oraz 74:25,4. Tak zbliżony wynik sugeruje użycie dokładnie tej samej farby, mimo 6 lat dzielących czas powstania obydwu dzieł. W praktyce sytuacja umożliwiająca tak dokładne porównania dla pigmentów obecnych na różnych obrazach występuje rzadko, gdyż jest uwarunkowana użyciem koloru w postaci czystej lub prawie czystej, najlepiej w grubym impaście. Znaczaco odmienna proporcja $\mathrm{Cd}$ do Se zmierzonego dla tego samego koloru, ale w innym fragmencie tego samego obrazu z niewielkim dodatkiem bieli ołowianej do czerwieni, unaocznia wagę dobrze wybranego punktu pomiarowego dla budowania właściwych proporcji zliczeń pierwiastków i ich dalszych porównań.

Najsilniej wygasza sygnał i pomniejsza wartość zliczeń innych pierwiastków ołów zawarty w bieli ołowiowej. Pojawia się ona w zdecydowanej większości obrazów badanego okresu i stanowi dodatek, często duży, do prawie wszystkich kolorów mieszanych na palecie. Badano również siłę ekranowania warstw ceruleum (zawierającego głównie cynę i kobalt) oraz oranżu kadmowego. W obu przypadkach jest ona mniejsza niż ołowiu, ale znacząca, nawet rzędu kilkunastu razy dla pierwiastków bardziej podatnych na ekranowanie. 
Dla czerwieni pokrytych warstwą/warstwami bieli ołowianej stosunek między kadmem a selenem został zachwiany, jako że kadm jest zdecydowanie mniej ekranowany niż selen (tab. 3, 4, rys. 1).

Tab. 3. Ekranowanie warstwy czerwieni kadmowej przez biel ołowianą oraz ceruleum. Widoczne silniejsze ekranowanie ołowiu w bieli niż cyny w ceruleum oraz większa podatność selenu niż kadmu na ekranowanie

\begin{tabular}{|l|c|c|c|c|}
\hline \multirow{2}{*}{$\begin{array}{l}\text { Czerwień kadmowa } \\
\text { CdS } \times \text { Cd Se }\end{array}$} & \multicolumn{3}{|c|}{ Wartości zliczeń pierwiastków } & \multirow{2}{*}{ Cd/Se } \\
\cline { 2 - 4 } & pokrywającego & Cd & Se & \\
\hline Czysta & & 15625 & 5040 & 0,32 \\
\hline Pokryta bielą & Pb 13065 & 4774 & 469 & 0,10 \\
\hline Czysta & & 14802 & 4642 & 0,31 \\
\hline Pokryta ceruleum & Sn 10035 & 12034 & 2336 & 0,20 \\
\hline Pokryta ceruleum & Sn 15544 & 10760 & 1621 & 0,15 \\
\hline
\end{tabular}

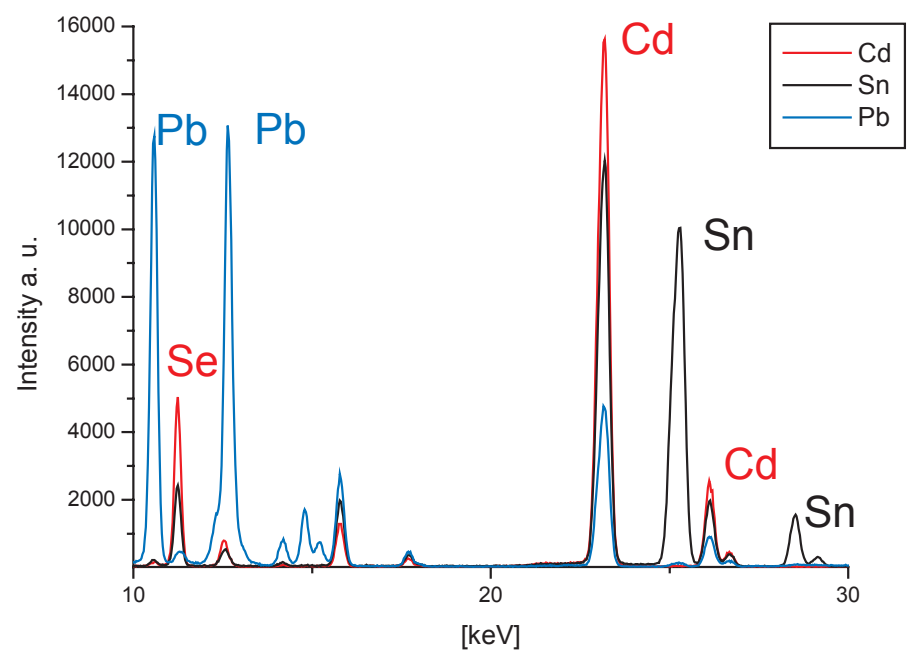

Rys. 1 . Widmo czystej
czerwieni $(\mathrm{Cd})$, pokrytej
warstwą ceruleum $(\mathrm{Sn})$
oraz bieli ołowianej $(\mathrm{Pb})$

Wpływ mieszanin w postaci absorpcji fluorescencji danego pierwiastka przez ołów z bieli ołowianej ilustruje tab. 5. Najsilniej ulega ekranowaniu żelazo (zwłaszcza w błękicie pruskim), chrom, kobalt, selen; w mniejszym stopniu - mangan, miedź, arsen, wapń, bar; słabo - kadm, cyna, cynk 5 .

5 Dla wapnia, baru i miedzi obserwacje przeprowadzono głównie na podstawie obrazów oryginalnych, a nie próbek - dla pierwszych dwóch przez porównywanie wartości otrzymywanych dla czystych gruntów, oraz na powierzchni warstwy malarskiej, natomiast dla mie- 
Tab. 4. Wpływ warstw ekranujących i ich grubości (wyrażonej wartością zliczeń) na spadek intensywności sygnału Cr w chromoksydzie

\begin{tabular}{|c|c|c|c|}
\hline \multirow{2}{*}{$\begin{array}{l}\text { Chromoksyd } \\
\mathrm{Cr}_{2} \mathrm{O}_{3}\end{array}$} & \multicolumn{2}{|c|}{ Wartości zliczeń pierwiastków } & \multirow{2}{*}{$\begin{array}{l}\text { Stosunek zliczeń } \\
\text { czystego Cr } \\
\text { do zakłóconego }\end{array}$} \\
\hline & $\begin{array}{l}\text { koloru domieszanego/ } \\
\text { /pokrywającego }\end{array}$ & czystego $\mathrm{Cr}$ & \\
\hline Czysty & & 4199 & \\
\hline Z bielą ołowianą & $\mathrm{Pb} 2995$ & 375 & 11,2 \\
\hline Czysty & & 9460 & \\
\hline Pokryty bielą & $\mathrm{Pb} 5767$ & 777 & 12,1 \\
\hline Czysty & & 6518 & \\
\hline Pokryty oranżem & Cd 10877 & 925 & 7 \\
\hline Pokryty oranżem & Cd 29216 & 198 & 33 \\
\hline Czysty & & 7530 & \\
\hline Pokryty ceruleum & Sn 10216 & 2296 & 3,3 \\
\hline Pokryty ceruleum & Sn 19158 & 494 & 15,2 \\
\hline
\end{tabular}

Tab. 5. Wartość zliczeń dla pigmentu czystego i w mieszaninie z bielą ołowianą. Widoczna silna absorpcja innych pierwiastków przez ołów obecny w bieli

\begin{tabular}{|c|c|c|c|c|}
\hline \multirow[b]{2}{*}{ Pigment } & \multirow{2}{*}{$\begin{array}{l}\text { Pierwiastek } \\
\text { „wiodacy” }\end{array}$} & \multicolumn{2}{|c|}{ Wartość zliczenia } & \multirow{2}{*}{$\begin{array}{c}\text { Stosunek } \\
\text { czysty/ } \\
\text { /w mieszaninie }\end{array}$} \\
\hline & & pigment czysty & zmieszany z bielą & \\
\hline Alizaryna & $\mathrm{Ca}$ & 801 & 493 & 1,6 \\
\hline Ugier & $\mathrm{Fe}$ & 1336 & 287 & 4,7 \\
\hline Chromoksyd & $\mathrm{Cr}$ & 4199 & 375 & 11,2 \\
\hline Fiolet manganowy & $\mathrm{Mn}$ & 2974 & 167 & 17,8 \\
\hline Oranż kadmowy & $\mathrm{Cd}$ & 10848 & 459 & 23,6 \\
\hline Błękit pruski & $\mathrm{Fe}$ & 2636 & 75 & 35,1 \\
\hline
\end{tabular}

Bardzo słabo ulegają ekranowaniu rtęć i ołów, jako pierwiastki ciężkie, o dużej liczbie atomowej ${ }^{6}$.

dzi poprzez zestawienia proporcji miedzi do arsenu w prawie czystej zieleni szwajnfurckiej, a następnie z domieszką do niej m.in. bieli ołowianej.

6 Również na podstawie obserwacji w obrazach. 
Istotna dla wartości zliczeń jest również grubość i układ warstw. W badaniach próbek czystych pigmentów współczesnych zaobserwowano w miarę stała, zbliżoną do liniowej, proporcje pierwiastków składowych pigmentu w warstwach o grubościach odpowiadających średniej wartości zliczeń pierwiastka wiodącego. Powyżej tej grubości liniowy charakter tych proporcji może zostać zachwiany, w różnym stopniu dla różnych pigmentów. Zasadniczo jednak w obrazie rzadko mamy do czynienia z grubościami przekraczającymi ten pulap.

Warstwy oddziaływały ze sobą na trzy sposoby: całkowite ekranowanie pierwiastków (wszystkich lub wybranych) obecnych w warstwie spodniej; sumowanie - wzmocnienie intensywności sygnału, gdy ten sam pierwiastek był obecny w obydwu warstwach (rys. 2); całkowite ekranowanie warstwy spodniej, gdy warstwa wierzchnia jest wystarczająco gruba, a poniżej pewnej grubości - determinowanie wartości zliczeń przez warstwe spodnią (rys. 3a, b).

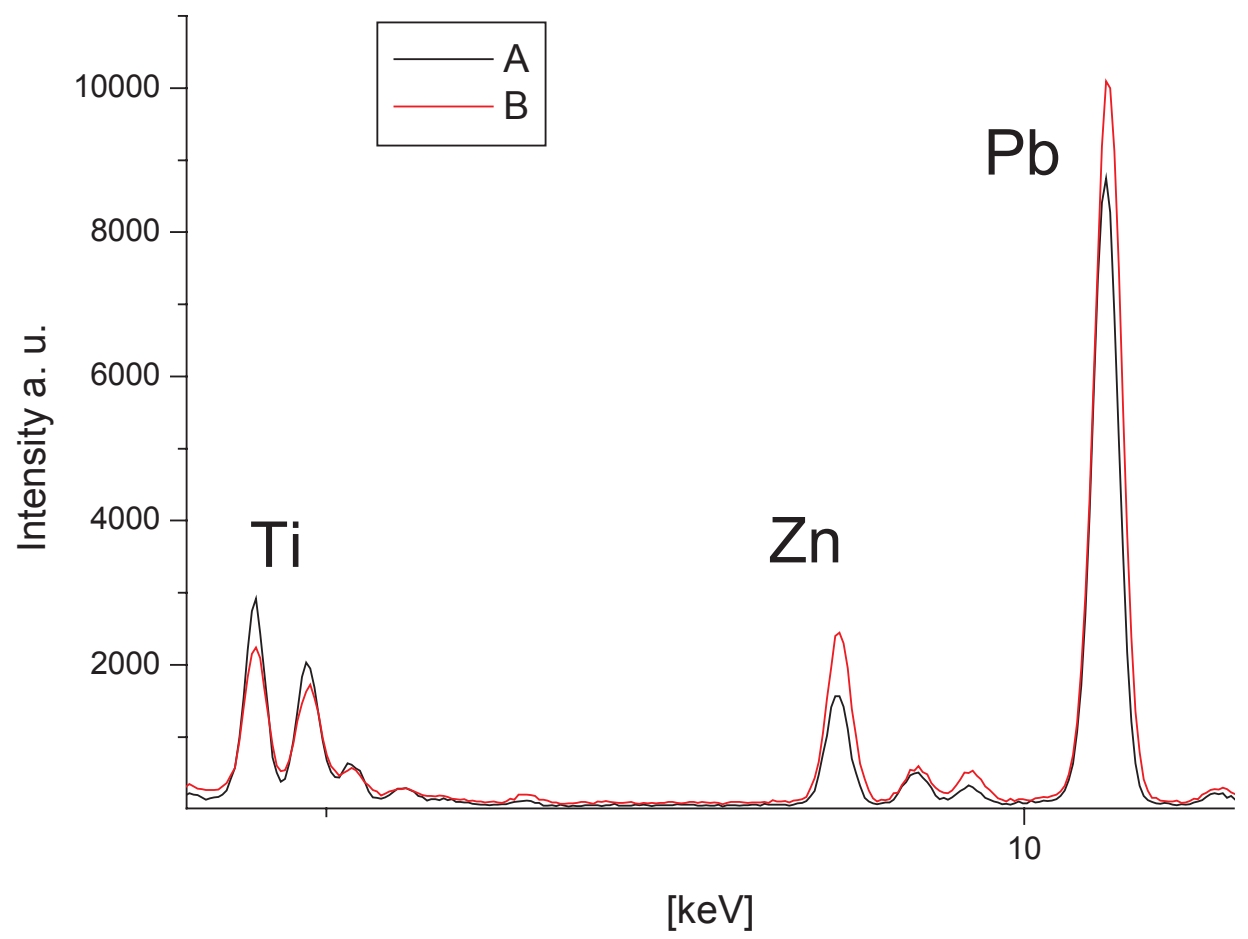

Rys. 2. Wzmacnianie sygnału pierwiastka, gdy jest on obecny w obydwu warstwach (warstwa bieli ołowiowej zawierającej $\mathrm{Pb}, \mathrm{Ti}, \mathrm{Zn}$, leżąca na podłożu zawierającym tytan - widmo A, oraz na podłożu zawierającym cynk - widmo B) 
a)

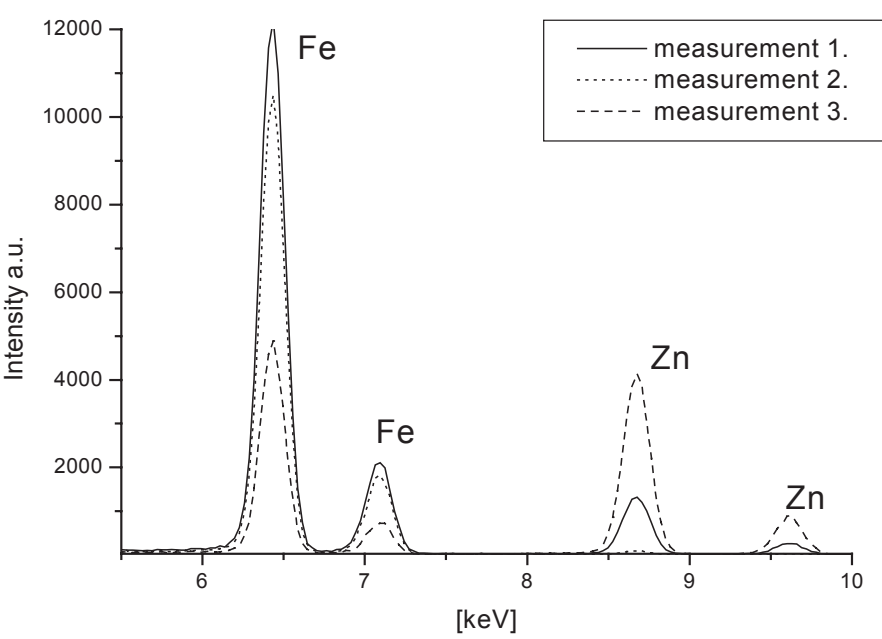

b)

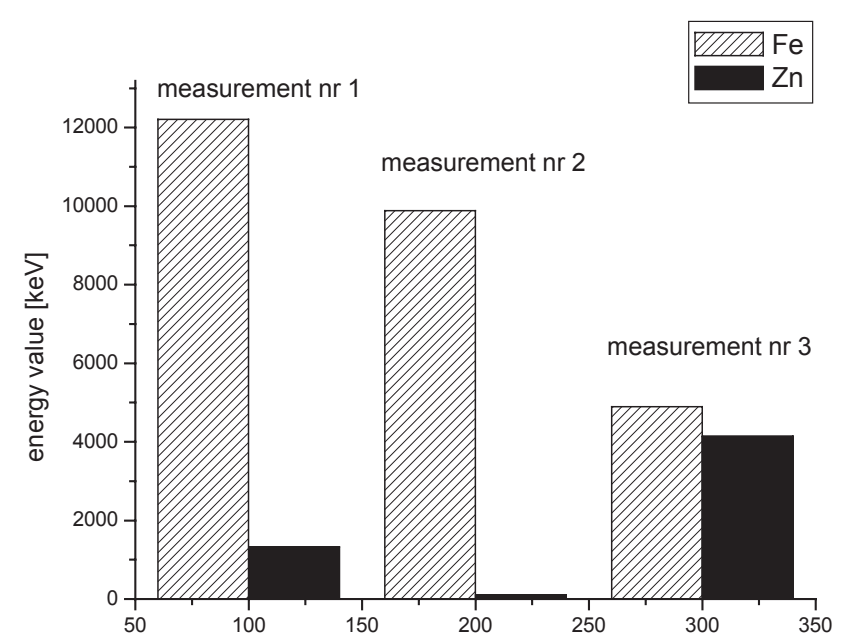

Rys. 3. Intensywność linii Fe i Zn dla ugru (zawierającego głównie żelazo i niewielkie ilości cynku), leżącego na podłożu zawierającym biel cynkową (główny składnik Zn). Grubość górnej warstwy maleje w kolejnych pomiarach. W pomiarze drugim ilość Zn spada proporcjonalnie do spadku ilości Fe w ugrze - brak wpływu warstwy spodniej, pomiar trzeci - wartość zliczeń dla Zn wzrasta gwałtownie determinowana przez warstwę spodnią gruntu - górna warstwa farby jest zbyt cienka, by nadal ją ekranować

Porządek ilości zliczeń jednego tylko pierwiastka charakterystycznego również pozwala na przybliżone odróżnianie niezmieszanych, czystych pigmentów i szeregowanie ich w przybliżeniu ze względu na wartość zliczeń wiodącego pierwiastka, nawet gdy jest on wspólny i ten sam dla kilku różnych pigmentów - tab. $6 \mathrm{a}, \mathrm{b}$. 
Tab. 6a, b. Pigmenty żelazowe i kobaltowe uszeregowane według wartości zliczeń pierwiastków charakterystycznych (próbki farb współczesnych)

a)

\begin{tabular}{|l|c|}
\hline Pigment & $\begin{array}{c}\text { Wartość zliczeń } \\
\text { Fe }\end{array}$ \\
\hline Umbra & 5118 \\
\hline Błękit pruski & 2636 \\
\hline Ugier & 1336 \\
\hline Róż angielski & 886 \\
\hline
\end{tabular}

b)

\begin{tabular}{|l|c|}
\hline Pigment & $\begin{array}{c}\text { Wartość zliczeń } \\
\text { Co }\end{array}$ \\
\hline Błękit kobaltowy & 11007 \\
\hline Fiolet kobaltowy & 5275 \\
\hline Ceruleum & 1654 \\
\hline Zieleń kobaltowa & 889 \\
\hline
\end{tabular}

W celu umożliwienia pełnej interpretacji wyników otrzymanych dla warstwy malarskiej na obrazach, gdzie kolory występują najcześciej w mieszaninach, przebadano również próbki czystych kolorów farb historycznych: z palety Matejki z 1888 roku oraz z kasety z tubkami farb anonimowego malarza datowanej po 1900 roku.

Ołowiana biel z palety Matejki zawiera obok ołowiu w mniejszych ilościach pierwiastki: $\mathrm{Zn}, \mathrm{Ca}, \mathrm{Cu}, \mathrm{Fe}, \mathrm{As}, \mathrm{Sb}, \mathrm{Sr}, \mathrm{Cr}, \mathrm{Mn}, \mathrm{Cd}$, a biele w tubkach z badanej kasety, wystepujące pod producencką nazwą - „srebrne”, oprócz ołowiu zawierają nieznaczne ilości Fe, Cr, Ti. W użytej przez Matejkę ciemnej żółcieni kadmowej stwierdzono obok kadmu Cu i Sr; w tubkach natomiast wypełniacz w postaci bieli cynkowej w charakterystycznych proporcjach do kadmu (dla próbek kolejnych żółcieni kadmowych nr 16, 17, 18 różnych firm stosunek kadmu do cynku wynosił odpowiednio: 3,5; 4,3; 2,3). Co ciekawe, jako jeden ze składników dodatkowych pojawia się w nich w niewielkich ilościach kobalt. Cynober firmy Sennelier (próbka nr 5) zawiera w ilościach śladowych tytan i biel ołowianą jako dodatek, firmy Lefranc biel cynkową (próbka nr 6). Wśród czerwieni organicznych osadzanych najczęściej na kredzie również wyróżniono charakterystyczne składniki dodatkowe, m.in. miedź i niewielkie ilości kobaltu. Wiele charakterystycznych dodatków zawierają też liczne pigmenty żelazowe, oprócz wiodącego żelaza i wypełniaczy ( $\mathrm{Ca}$ - kreda lub gips, $\mathrm{Zn}$ - biel cynkowa, $\mathrm{Pb}$ - ołowiowa, $\mathrm{Ba}-$ szpat), także Mn, Sr, As, Sn, Cr, Ti, Cd w różnych kombinacjach, pozwalających niejednokrotnie na ich rozróżnienie. Wśród błękitów kobaltowych 
wyróżnia się farba zawierająca obok kobaltu znaczące ilości niklu (nr 39) 7 . Pierwiastek ten nie był dotychczas odnotowywany w literaturze jako charakterystyczny, podobnie jak wanad stwierdzony w farbie oferowanej przez Lefranc Bourgeois jako róż francuski. W błękitach w niewielkich ilościach jest obecny tytan, a także chrom i stront. Fiolet kobaltowy ciemny nr 47 to prawdopodobnie fosforan kobaltu. Sugestia ta jest możliwa dzięki wykluczeniu innego fioletu kobaltowego, zawierającego obok kobaltu również arsen.

Znacznym rozszerzeniem możliwości i informacji dotyczących identyfikacji są nie tylko pierwszy raz identyfikowane w znaczących ilościach nikiel i wanad, ale i wskazanie tytanu jako składnika kilku różnych tlenków żelazowych na palecie już z 1888 roku, a także w wielu farbach z nieco późniejszej kasety (tab. 7) (w bielach, żółcieni, błękitach, zieleni, a zwłaszcza w brązach

Tab. 7. Pierwiastki dodatkowe wybranych kolorów (obecność wynikająca z dodatku wypełniacza, nośnika dla barwników, zanieczyszczeń naturalnych bądź wynikających ze sposobu produkcji). Podkreślono pierwiastki występujące w ilościach znaczących, umożliwiających budowanie proporcji i porównań ilościowych. Pierwiastki niepodkreślone występują w ilościach śladowych

\begin{tabular}{|c|c|c|c|c|}
\hline \multirow[b]{2}{*}{ Farba } & \multirow[b]{2}{*}{$\begin{array}{c}\text { Pier- } \\
\text { wiastek } \\
\text { wiodący }\end{array}$} & \multicolumn{3}{|c|}{ Pierwiastki dodatkowe } \\
\hline & & $\begin{array}{l}\text { paleta Matejki } \\
\text { (1888) }\end{array}$ & $\begin{array}{l}\text { tubki z kasety } \\
\text { (po 1900) }\end{array}$ & $\begin{array}{c}\text { farby } \\
\text { współczesne } \\
\text { (Talens) }\end{array}$ \\
\hline Biel ołowiowa & $\mathrm{Pb}$ & $\begin{array}{c}\mathrm{Zn}, \mathrm{Ca}, \mathrm{Cu}, \mathrm{Fe}, \mathrm{As}, \\
\mathrm{Sb}\end{array}$ & $\mathrm{Fe}, \mathrm{Cr}, \mathrm{Ti}$ & $\begin{array}{c}\mathrm{Ti}, \underline{\mathrm{Zn}}, \underline{\mathrm{Ba}}, \\
\mathrm{Sr}, \mathrm{Sn}\end{array}$ \\
\hline Cynober & $\mathrm{Hg}$ & $\mathrm{Zn}, \mathrm{Pb}, \mathrm{Fe}$ & $\underline{\mathrm{Pb}}, \mathrm{Zn}, \mathrm{Sr}, \mathrm{Ti}, \mathrm{Ca}, \mathrm{Sn}$ & \\
\hline Żółcień kadmowa & $\mathrm{Cd}$ & $\underline{\mathrm{Cu}}, \underline{\mathrm{Sr}}, \mathrm{Sb}, \mathrm{Cr}, \mathrm{Pb}, \mathrm{Fe}$ & $\mathrm{Pb}, \mathrm{Co}, \mathrm{Zn}$ & $\underline{\mathrm{Zn}}, \mathrm{Ba}$ \\
\hline Błękit kobaltowy & $\mathrm{Co}$ & $\mathrm{Fe}, \mathrm{Pb}, \mathrm{Ca}$ & $\underline{\mathrm{Ni}}, \mathrm{Ca}$ & $\underline{\mathrm{Zn}}, \mathrm{Ca}, \mathrm{Cr}, \mathrm{Fe}$ \\
\hline Czerwień żelazowa & $\mathrm{Fe}$ & $\mathrm{Sb}, \mathrm{Sn}, \mathrm{Cd}$ & $\mathrm{Pb}, \mathrm{Ca}$ & \\
\hline $\begin{array}{l}\text { Czerwień } \\
\text { organiczna }\end{array}$ & & $\underline{\mathrm{Pb}}, \mathrm{Co}, \mathrm{Cu}, \mathrm{Sb}, \mathrm{Sn}$, & $\underset{\mathrm{Cr}}{\mathrm{Ca}, \mathrm{Sn}, \mathrm{Pb}, \mathrm{Fe}, \mathrm{Sb},}$ & $\begin{array}{l}\mathrm{Sr}, \mathrm{Cr}, \mathrm{Ti}, \\
\mathrm{Cr}, \mathrm{Fe}\end{array}$ \\
\hline Zieleń szwajnfurcka & $\mathrm{Cu}, \mathrm{As}$ & $\mathrm{Fe}, \mathrm{Ca}$ & $\mathrm{Pb}, \mathrm{Fe}$ & \\
\hline
\end{tabular}

7 O modyfikacjach producenckich oferowanych w XIX w. farb pisze: L. Carlyle, $A u$ thenticity and adulteration: What materials were 19th century artists really using?, „The Conservator", 1993, no. 17, s. 56-60; oraz J. H. Townsend, L. Carlyle, N. Khandekar, S. Woodcock, Later nineteenth century pigments: evidence for additions and substitutions, „The Conservator”, 1995 , no. 19 , s. $65-78$. 
i ochrach żelazowych). Stąd nie można, tak jak dotychczas, w sposób automatyczny przesuwać daty powstania dzieł na lata po 1920 roku (przybliżony okres wprowadzenia na rynek bieli tytanowej) tylko na podstawie stwierdzenia występowania tytanu w próbkach. Kluczowa okazała się, obok analizy jakościowej, przybliżona analiza ilościowa, pozwalająca, gdy bada się powierzchnię całego obrazu, odróżnić ilości tytanu obecnego jako naturalna lub producencka domieszka do różnych kolorów, od bieli ołowianej zawierającej tytan, dającej zdecydowanie wyższe wartości zliczeń. Podobnie w przypadku arsenu, który - jak się okazuje - występuje nierzadko jako składnik dodatkowy m.in. w tlenkach żelazowych i innych pigmentach, gdy jednak obecny jest w większych ilościach z towarzyszącą mu miedzią - wskazuje na zieleń szwajnfurcką. Porównanie wartości zliczeń umożliwia odróżnienie niewielkich dodatków od ilości arsenu jako pierwiastka wiodącego w zieleni szwajnfurckiej bądź fiolecie kobaltowym jasnym (arsenian kobaltu). Analogicznie kobalt lub miedź mogą wskazywać na konkretną czerwień lub tlenek żelazowy danego producenta jako pierwiastki występujące w ilościach śladowych albo błękit lub zieleń, gdy są identyfikowane w ilościach dużych jako pierwiastek wiodący.

Stwierdzone dodatki w postaci wypełniaczy, nośników, składników dodatkowych wynikających ze sposobu produkcji lub naturalnych zanieczyszczeń w ilościach znaczących pozwoliły na bardziej szczegółową identyfikację. W kasecie anonimowego malarza rozróżniono np. 4 blękity kobaltowe (tab. 8, rys. 4), 2 cynobry, 5 czerwieni organicznych. Nie wszystkie kolory różnią się wystarczająco składnikami lub ich proporcjami, by w sposób pewny odróżniać je w trakcie ewentualnych badań w mieszaninach już na obrazie. Niewątpliwie jednak dla wszystkich kolorów dostępnych w postaci czystej możliwe jest śledzenie subtelnych zmian w użyciu farb na paletach, wynikających nawet tylko ze zmiany producenta w obrębie tego samego koloru, lub rozstrzyganie, czy dana paleta posłużyła do namalowania danego obrazu (grupy obrazów). 
Tab. 8. Skład czterech czystych kolorów historycznych - błękitu kobaltowego z tubek z kasety - składniki dodatkowe i pierwiastki śladowe pozwalają na rozróżnienie konkretnej oferty producenckiej w obrębie jednego pigmentu

\begin{tabular}{|c|c|c|}
\hline $\begin{array}{c}\text { Błękit } \\
\text { kobaltowy } \\
\text { (tubki } \\
\text { z kasety) }\end{array}$ & $\begin{array}{c}\text { Pier- } \\
\text { wiastek } \\
\text { wiodący }\end{array}$ & $\begin{array}{c}\text { Pierwiastki } \\
\text { dodatkowe }\end{array}$ \\
\cline { 1 - 1 } Numer 12 & \multirow{4}{*}{ Co } & $\mathrm{Ti}, \mathrm{Sr}$ \\
\cline { 1 - 1 } Numer 30, & $\begin{array}{c}\mathrm{Ti}, \mathrm{Cr}, \mathrm{Cr}, \\
\mathrm{Pb}, \mathrm{Fe}\end{array}$ \\
\cline { 1 - 1 } Numer 34 \\
\cline { 1 - 1 } Numer 39 & $\mathrm{Ni}, \mathrm{Ca}$ \\
\hline
\end{tabular}

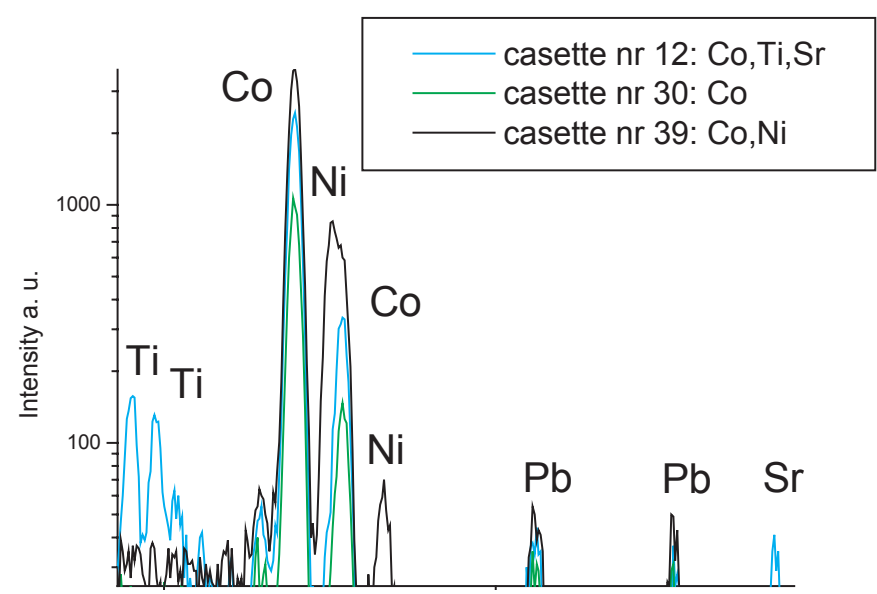

Rys. 4. Spektra błękitów kobaltowych z tubek historycznych z kasety malarskiej

Mimo trudności w interpretacji, również dla warstw malarskich badanych bezpośrednio na obrazie, możliwe jest określanie wypełniaczy i innych składników charakterystycznych. W impresjonistycznych obrazach Pankiewicza z roku 1890 w ultramarynie stwierdzono niewielkie ilości Zn, wskazujące na producencki dodatek bieli cynkowej (biel okazu stanowi biel ołowiowa). W przypadku żółcieni kadmowych natomiast w postaci zanieczyszczenia identyfikowano niewielką ilość antymonu.

Tab. 9. Wybrane biele ołowiane różniące się składem i czasem powstania (użycia)

\begin{tabular}{|l|c|c|c|c|c|c|c|c|c|}
\hline \multirow{2}{*}{$\begin{array}{l}\text { Pochodzenie bieli } \\
\text { olowianej }\end{array}$} & \multicolumn{7}{|c|}{ Zawartó́ć pierwiastków \% (poniżej 1\% - x) } & \multicolumn{2}{c|}{ Inne } \\
\cline { 2 - 12 } & $\mathrm{Pb}$ & $\mathrm{Ba}$ & $\mathrm{Zn}$ & $\mathrm{Ti}$ & $\mathrm{Ca}$ & $\mathrm{Sr}$ & $\mathrm{Cr}$ & $\mathrm{Fe}$ & \\
\hline Paleta (nr 24), 1888 & 92 & & 2 & & 2 & & $\mathrm{x}$ & $\mathrm{x}$ & $\mathrm{As}, \mathrm{Mn}$, \\
\hline Lato, 1890 & 97,5 & $\mathrm{x}$ & & & & $\mathrm{x}$ & $\mathrm{x}$ & $\mathrm{x}$ & $\mathrm{Cu}, \mathrm{Cd}, \mathrm{Sb}$ \\
\hline Autoportret, 1904 & 99 & $\mathrm{x}$ & $\mathrm{l}$ & $\mathrm{x}$ & $\mathrm{x}$ & $\mathrm{x}$ & $\mathrm{x}$ & $\mathrm{x}$ & $\mathrm{Cd}, \mathrm{Sn}$ \\
\hline Kaseta (nr 31), po 1900 & 98 & & & $\mathrm{x}$ & & & $\mathrm{x}$ & $\mathrm{x}$ & \\
\hline Koszyk, 1938 & 91 & 4 & $?$ & 5 & & 1 & $\mathrm{x}$ & $\mathrm{x}$ & $\mathrm{Sn}$ \\
\hline Współczesna (Talens) & 67 & $5-6$ & 8 & 14 & & 4 & & $\mathrm{x}$ & $\mathrm{Sn}$ \\
\hline
\end{tabular}


Tab. 10. Główne składniki współczesnej bieli ołowianej (zawierającej Pb, Zn, Ba, $\mathrm{Sr}, \mathrm{Ti}$ ). Tytan zawarty również w gruncie podobrazia wzorcowego został pominięty. Widoczna stabilność proporcji składników bieli względem siebie

\begin{tabular}{|l|c|c|c|c|}
\hline \multirow{2}{*}{ Biel ołowiana w mieszaninie z: } & \multicolumn{4}{|c|}{ Proporcje zliczeń poszczególnych pierwiastków } \\
\cline { 2 - 5 } & $\mathrm{Pb}$ & $\mathrm{Ba}$ & $\mathrm{Zn}$ & $\mathrm{Sr}$ \\
\hline Czystą bielą ołowianą & 0,68 & 0,14 & 0,15 & 0,04 \\
\hline Czernią kostną & 0,67 & 0,12 & 0,16 & 0,04 \\
\hline Fioletem manganowym & 0,67 & 0,11 & 0,18 & 0,05 \\
\hline Ugrem & 0,66 & 0,12 & 0,17 & 0,05 \\
\hline Alizaryną & 0,67 & 0,10 & 0,18 & 0,04 \\
\hline Oranżem kadmowym & 0,66 & 0,10 & 0,18 & 0,05 \\
\hline
\end{tabular}

Badania poszerzyły znacznie zakres wiedzy na temat składu samych pigmentów i stanowią zrąb tworzenia szerszej bazy dokładnie wydatowanych i oznaczonych pod względem składu farb i pigmentów, niezbędnych do porównań w trakcie precyzyjnych badań warstwy malarskiej na obrazie ${ }^{8}$.

Szczególnie obiecujące wydają się pod tym względem biele, występujące praktycznie na każdym obrazie i jednocześnie zmieniające swój skład w zależności od czasu produkcji i producenta (tab. 9). Ponadto, zwłaszcza w przypadku bieli ołowianej, pozostają one w dość trwałych, niezależnych od ekranowania i absorpcji proporcjach pierwiastków względem siebie, pozwalając na miarodajne porównania (tab. 10).

Zalety metody, w stosunku do dotychczas stosowanych sposobów oznaczania składu pierwiastkowego pigmentów, to: pełna nieinwazyjność (brak potrzeby pobierania próbek), możliwość wykonania badania in situ, zwiększenie czułości (i rozdzielczości energetycznej), obok analizy jakościowej

8 Szczegółowo budowę różnych odmian żółcieni chromowych w XIX w. oraz ich wypełniacze analizują np. A. B. Burnstock, C. G. Jones, G. Cressey, Characterisation of artists' chromium based yellow pigments, „Zeitschrift für Kunsttechnologie und Konservierung”, 2003/17, H. 1, s. 75-84; studium porównawcze składu pierwiastkowego i budowy krystalicznej trzech żółcieni chromowych, błękitów kobaltowych oraz zieleni szwajnfurckiej znajduje się w: B. Fruhmann, M. Schreiner, M. Mantler, Anorganische historische Pigmente einer Pigmentsammlung in Wien: Identifizierung zur Erstellung einer Datenbank, „Zeitschrift für Kunsttechnologie und Konservierung", 2003/17, H. 2, s. 297-298. 
wprowadzenie analizy quasi-ilościowej, łatwość zastosowania i krótki czas pomiaru, pozwalający na identyfikację w nieograniczonej liczbie punktów bez uszczerbku dla obrazu. Ponadto technika ta pozwala na otrzymywanie informacji o składzie pierwiastkowym również dla warstw spodnich, zależnie od przenikliwości warstw wierzchnich. Dotychczas stosowana w Polsce analiza fluorescencji rentgenowskiej do identyfikacji wymagała pobrania próbek z obiektu ${ }^{9}$. Miała ponadto mniejszą czułość, nie dając także zasadniczo podstaw do analizy ilościowej. A to właśnie analiza ilościowa okazała się w niektórych przypadkach kluczowym narzędziem identyfikacji pozwalającej na odróżnianie np. bieli barytowej zawartej w gruncie obrazu od stanowiącej wypełniacz innych kolorów lub barytu stanowiącego składnik żółcieni barytowej. Tych możliwości nie daje także inna nieinwazyjna metoda - reflektografia w podczerwieni w technice fałszywych kolorów. Obrazuje ona występowanie niektórych kolorów na licu obrazu ${ }^{10}$. Nie pozwala jednak na szczegółowe rozróżnienie np. żółcieni kadmowych od chromowych czy fioletu kobaltowego od błękitu kobaltowego (czasami dających bardzo podobne wartości optyczne, mimo użycia w zupełnie różnych mieszaninach kolorów na tym samym obrazie).

Czułość przenośnego spektrometru ilustruje zestawienie wyników otrzymanych dla tych samych obrazów na podstawie próbek badanych metodą spektralnej analizy emisyjnej spektrometrem Mini Pal PW 4025, a następnie z użyciem przenośnego spektrometru XRF do badania bezpośrednio powierzchni obrazów.

W obrazie Targ na kwiaty (1890) ${ }^{11}$, z którego pobrano 12 próbek, badanie aparatem Mini Pal wykazało w poszczególnych próbkach obecność pierwiastków: $\mathrm{Pb}, \mathrm{Zn}, \mathrm{Fe}, \mathrm{Ca}, \mathrm{Hg}, \mathrm{Cu}, \mathrm{As}, \mathrm{Cr}, \mathrm{Ba}$. Na tej podstawie zidentyfikowano: biel ołowianą, cynober, czerwień organiczną ${ }^{12}$, zieleń szwajnfurcką, ultramarynę lub błękit organiczny, żółcienie chromowe. Badanie przenoś-

9 W ZTiTM, UMK Toruń, jest to spektrometr Mini Pal PW 4025.

10 J. Rogóż, Fotografia kolorowa w bliskiej podczerwieni "technika fałszywych kolorów", [w:] Materiaty z konferencji od badań do konserwacji, Toruń, 23-24 października 1998, s. $225-235$.

11 Własność Muzeum Narodowego w Poznaniu, nr inw. MP 112.

12 Poprzez wykluczenie innych czerwieni; pomiary na próbkach wyk. mgr A. Cupa, ZTiTM, UMK Toruń. 
nym spektrometrem XRF bez pobrania próbek pozwoliły na stwierdzenie wszystkich wyżej wymienionych pierwiastków i pigmentów oraz zidentyfikowanie kolejnych: żółcieni kadmowej (z wypełniaczem w postaci bieli cynkowej Zn oraz zanieczyszczeniem Sb), zieleni szmaragdowej, błękitu kobaltowego, umbry. Ponadto żółcień chromową scharakteryzowano jako chromową strontową, a w czerwieni organicznej zidentyfikowano cyne ${ }^{13}$. Za pomocą badań na próbkach aparatem Mini Pal w ogóle nie stwierdzono obecności w próbkach pierwiastków: Cd, Sn, Sr, Co, Mn, Sb.

Dla kolejnego obrazu - Targ za Żelazna Brama (1888)14 - przenośnym spektrometrem XRF potwierdzono wszystkie zidentyfikowane wcześniej aparatem Mini Pal pigmenty i pierwiastki (na podstawie badań 7 pobranych próbek pierwiastki: $\mathrm{Ca}, \mathrm{Pb}, \mathrm{Cr}, \mathrm{Fe}, \mathrm{Hg}, \mathrm{Ba}, \mathrm{Co}, \mathrm{Zn}, \mathrm{Cu}$; pigmenty: biel ołowiana, cynober, żółcień chromowa, błękit pruski, zieleń miedziowa, błękit kobaltowy), identyfikując ponadto pierwiastki: Sb, As, Mn, Sr, Cd, Sn, Sb; pigmenty: biel cynkową, żólcień kadmową, żółcień neapolitańską, zieleń szwajnfurcką (obok miedzi zidentyfikowano arsen), prawdopodobnie szmaragdową, sienę, umbre, prawdopodobnie ugier. Ponadto żółcienie zawierające chrom scharakteryzowano jako żółcień strontową i barytową, a w czerwieni organicznej stwierdzono obecność cyny.

Mniejsza liczba pierwiastków zidentyfikowanych aparatem Mini Pal wynika nie tylko z ograniczenia ilości pobranych próbek, ale i ze znacznie węższego spektrum energetycznego, niepozwalającego na stwierdzanie linii $\mathrm{K}$ np. dla kadmu, cyny, antymonu, utrudniającego lub prawie uniemożliwiającego ich identyfikacje, gdy występują w mniejszej ilości lub z pierwiastkami o sąsiadujących z nimi pikach, co wynika również z niższej rozdzielczości

13 Prawdopodobnie w tlenku cyny, ewentualnie chlorku cyny, używanych jako składnik nośnika dla barwnika organicznego (w obrazach impresjonistów francuskich, Moneta Dworzec Saint Lazare, również stwierdzano taki substrat), patrz D. Bomford et al., Art in the making Impressionism, London 1990, s. 71. Trudno w pewny sposób rozstrzygać dokładnie, w jakim związku - jedni autorzy sugerują tlenek cyny: D. Bomford et al., op. cit., s. 71, inni również chlorek cyny: A Closer Look, Technical and Art-Historical Studies on Works by Van Gogh and Gauguin, ed. C. Peres, L. van Tilborgh, M. Hoyle, Amsterdam 1991, s. 77. Por. J. H. Hofenk de Graaff, Natural Dyestuffs: Origin, Chemical Constitution, Identification, ICOM Committee for Conservation, 2nd Triennial Meeting, Amsterdam 1969.

14 Własność Muzeum Narodowego w Poznaniu, nr inw. MP 113. 
w stosunku do przenośnego spektrometru XRF ${ }^{15}$. Utrudnia to identyfikację żółcieni kadmowej, żółcieni neapolitańskiej (a w przypadku Pankiewicza nierzadkie jest stosowanie tych żółcieni na jednym obrazie, a nawet w połączeniu dodatkowo z żółcieniami chromowymi), ceruleum oraz cyny w substracie czerwieni organicznej.

Porównując wyniki dla przeszło 10 obrazów, stwierdzono także rzadszą identyfikację błękitu kobaltowego (Co), żółcieni strontowej (Sr) czy zieleni szwajnfurckiej. Dla zieleni na aparacie Mini Pal dość często stwierdzana była miedź, rzadko jednak z charakterystycznym dla niej również arsenem, co mogło dawać wrażenie, że jest to np. zieleń Scheelego (zasadowy chlorek miedziowy), a nie szwajnfurcka (arsenooctan miedziowy). W ogóle nie identyfikowano także manganu wskazującego na obecność ziemnych tlenków żelazowych (umbry). Stosując przenośny spektrometr XRF, dla większości obrazów uzyskiwano paletę o kilka kolorów poszerzoną w stosunku do metody tradycyjnej, mimo niepobierania próbek.

Badając obrazy Pankiewicza przenośnym spektrometrem XRF, potwierdzono również wyniki badań pigmentów na podstawie dwóch palet Pankiewicza z Muzeum Narodowego w Warszawie ${ }^{16}$ i poszerzono spektrum oznaczonych dla całej twórczości Pankiewicza pigmentów o żółcień strontową, cynkową, neapolitańską, aureolinę, czerwień kadmową, czerwień żelazową, błękit pruski, zieleń szwajnfurcką, zieleń kobaltową, zielenie cynobrowe, czerń żelazową, kostną oraz prawdopodobnie czerń kobaltową.

Z powyższej grupy pigmentów nie zidentyfikowano dotychczas na obrazach za pomoca przenośnego spektrometru obecnych na palecie według autorki: masykotu ${ }^{17}$ oraz bieli barytowej jako czystego koloru (identyfikowano jedynie szpat jako dodatek do gruntów lub wypełniacz innych kolorów).

15 M. Sawczak, A. Kamińska, M. Poksińska, A. Cupa, G. Śliwiński, op. cit., s. 73-74.

16 A. Lewandowska, Aspekty techniczno-technologiczne w obrazach Józefa Pankiewicza, s. XXXVI-XLVIII, [w:] Józef Pankiewicz. Życie i dzieło. Artyście w 140. rocznice urodzin, katalog wystawy, Muzeum Narodowe w Warszawie, 9 stycznia-26 marca 2006.

17 Niestety, nie podano metod identyfikacji pigmentów, zaskakuje jednak obecność masykotu. Jego występowanie na palecie współczesnej jest rzadkie, częstsze jako sykatywy, z która gotowano olej. W literaturze znajdujemy informacje o używaniu tego pigmentu w XIX w. przez A. Böcklina, eksperymentującego z materiałami i technikami historycznymi: E. L. Richter, H. Härlin, The pigmets of the Swiss nineteenth century painter Arnold Böcklin, 
Ponadto dzięki uwzględnieniu trzydziestu dziewięciu wydatowanych obrazów dla niektórych pigmentów ustalono rok ich pojawienia się w twórczości Pankiewicza. Fiolet kobaltowy pojawia się pierwszy raz na dotychczas badanych obrazach w roku 1908, co pozwala datować jedną z palet, na której stwierdzono ten pigment, na czas nie wcześniejszy niż 1908 rok. Czerwienie kadmowe pojawiają się w okresie hiszpańskim od roku 1917, zieleń kobaltowa upowszechnia się w drugiej połowie lat 20., a dodatek bieli tytanowej do ołowiowej w latach 30.

\section{Podsumowanie}

Istotne jest, by badania spektrometrem XRF kolorów użytych na licu poprzedziły analizy w świetle UV oraz IR. Są one pomocne we wstępnym określeniu rodzaju pigmentu oraz jego zasięgu, a także uwidaczniają ingerencje konserwatorskie, co pozwala uniknąć wykonywania pomiarów warstw wtórnych. Może je również wspomagać technika fałszywych kolorów w podczerwieni (zwłaszcza dla trudnego w identyfikacji metodą XRF błękitu pruskiego). Ponadto pomiary dla warstwy malarskiej, o ile to tylko możliwe, powinny poprzedzać pomiary dla czystego gruntu, często zachowanego w postaci odkrytej na zawiniętej z tyłu krajce, szczególnie dla podobrazi wykonanych na płótnie fabrycznym.

Badania przenośnym spektrometrem XRF są narzędziem pozwalającym identyfikować szeroką paletę pigmentów, a przy uwzględnieniu zasygnalizowanych ograniczeń - do pewnego stopnia również na ocenę ilościową składu pierwiastkowego poszczególnych pigmentów, znajdujących się w warstwie malarskiej.

„Studies in Conservation”, 1974, no. 19, s. 83-87. Używał go też Michałowski, niemniej XIX-wieczne źródła w listach pigmentów właściwie go nie ujmują (por. przypis 32, J. Szpor, Michałowski nieznany, Warszawa 1991, s. 98), stąd rodzi się pytanie, czy sugerowanie masykotu nie jest spowodowane niedoskonałością użytych metod analitycznych. Jony ołowiu obok masykotu zawiera zarówno biel ołowiana, jak i żółcień chromowa. Rozstrzygająca mogłaby być analiza XRD. 
Analiza ilościowa pozwoliła na rozstrzygnięcie, czy biel tytanowa stanowi składnik gruntu (gdy jest obserwowana na stałym, niskim poziomie na całej powierzchni obrazu), czy użyto jej jako czystej bieli (silny sygnał w przebielonych partiach), czy - jak w przypadku obrazu Koszyk z owocami $(1938)^{18}$ - wartość zliczeń dla tytanu jest średnia i proporcjonalna do ilości zliczeń ołowiu, a więc stanowi składnik gotowej bieli (z domieszką także bieli barytowej) - mieszaniny producenckiej, niespotykanej w obrazach wcześniejszych. Również zidentyfikowanie baru jako niewielkiej domieszki do tej samej bieli ołowiowej na tym obrazie mogło być stwierdzone tylko ze względu na porównania wartości zliczeń, gdyż bar pojawiał się jako składnik gruntu w każdym pomiarze, niemniej dla bieli wartość zliczeń baru w stosunku do innych pomiarów wyraźnie wzrastała.

Ze względu na zakres identyfikowanych pierwiastków niemożliwa jest pewna detekcja takich pigmentów, jak czerń weglowa czy ultramaryna (można domniemywać o ich obecności poprzez wykluczenie innych), oraz barwników organicznych (choć daje się identyfikować nośniki, na których zostały osadzone). Pewne pigmenty nadal pozostają trudne do rozpoznania z powodu niskich wartości zliczeń (błękit pruski) lub ze względu na to, że identyfikowany pierwiastek jest wspólny dla kilku pigmentów. Mimo jednak tych ograniczeń, zarówno nieinwazyjność badań, względna łatwość aplikacji, jak i szybkość pomiaru, a zwłaszcza jego dokładność i możliwość analiz quasi-ilościowych obok jakościowych, czynią z przenośnego spektrometru XRF cenne narzędzie, znacznie poszerzające dotychczasowe możliwości identyfikacji pigmentów nieorganicznych w malarstwie olejnym. Jest to metoda szczególnie przydatna do badań malarstwa budowanego w niewielkiej ilości warstw lub alla prima oraz operującego nasyconym kolorem.

Dalsze szczegółowe badania zarówno na obrazach, jak i na czystych kolorach historycznych (palety, kasety malarskie), pod kątem zmieniającego się w czasie składu pierwiastkowego bądź obecności pewnych charakterystycznych nośników, wypełniaczy czy zanieczyszczeń w danych kolorach, mogą być w przyszłości podstawą do datowania samego obiektu i orzekania o jego autorstwie, a w niektórych przypadkach, nawet do przypisywania poszcze-

18 Własność Muzeum Narodowego w Poznaniu, nr inw. MP 3271. 
gólnym farbom o charakterystycznym składzie identyfikowanym na obrazie konkretnego producenta. Zarysowane możliwości metody, a zwłaszcza jej nieinwazyjność, pozwalają widzieć w niej w nadchodzących latach jedną z najbardziej obiecujących technik analitycznych dla badacza techniki i technologii malarstwa.

\section{Summary}

\section{Non-invasive method of the in situ identification of pigments - the analysis of oil paintings by Józef Pankiewicz with portable XRF-spectroscope}

The elementary composition of selected pigments in 39 oil paintings by Józef Pankiewicz, dating back to the years 1888-1938, has been determined with the use of a portable XRF-spectrometer built in the Institute of Fluid-Flow Machinery, Polish Academy of Sciences in Gdańsk. The analysis was preceded by tests on samples of modern paints. To compare with the tests results obtained on the paint layers from paintings also the samples of pure historical paints from Jan Matejko palette from 1888 have been tested as well as paints form tubes preserved in a cassette of anonymous painter, sated back to early $20^{\text {th }}$ century.

The detection range of the spectrometer covers the elements of the atomic number $50>Z>18$. A high-energy source of excitation has been employed (IS601.5, Italstructures) producing a collimated beam of $4 \mathrm{~mm}$ diameter and a detector (AXAS, Ketek) of high energetic resolution (FWHM $<=155 \mathrm{eV}$ for the $\mathrm{Mn}_{\mathrm{K} \alpha}$ line) and high sensitivity, which allowed for detecting even trace amounts of elements in paint layer. Basing on the measurements the average volume of the lines of elements present in particular pigments has been established, as well as the factors influencing their value. Detection of the elements: $\mathrm{Pb}, \mathrm{Zn}, \mathrm{Cr}, \mathrm{Cd}, \mathrm{Cu}, \mathrm{As}$, $\mathrm{Co}, \mathrm{Fe}, \mathrm{Hg}, \mathrm{Sr}, \mathrm{Ba}, \mathrm{Sn}, \mathrm{Sb}, \mathrm{Ti}, \mathrm{Ca}, \mathrm{Se}, \mathrm{Mn}$ in the paint layer of paintings allowed to identify led-, zinc-and titanium-white, ochre, chrome-, strontium-, zinc, Neapolitan and cadmium-yellow, vermilion, cadmium- and iron-red, cerulean- and Prussian blue, cobalt-violet, emerald-, Schweinfurter and vermilion-green, green earth, 
sienna, umber, iron-, bone and cobalt-black. Apart from the above the composition of primings, extenders added to paints and in cases where it was not based on light elements - the base of organic red. Some pigments turned out to be dating ones (the first use of cobalt-violet - 1908, of cadmium-red - 1919, titanium-white ca. 1938).

The advantages of this method, in relation with the methods of determining the elementary composition of paints used so far are: complete non-invasiveness, testing in situ, high sensibility (of energetic resolution), introducing a quasiquantitative analysis next to the qualitative one, easiness of use and short time of measurements. Besides, this technique allows also for obtaining information on the elementary composition of lower strata, depending on the permeability of upper ones. 